\title{
PENGARUH PERBEDAAN INDIVIDU TERHADAP KEPUTUSAN MENGGUNAKAN SISTEM OPERASI LINUX
}

\author{
Yuliana \\ Universitas Pendidikan Indonesia \\ Yulianasajaa08@gmail.com \\ Eded Tarmedi \\ Universitas Pendidikan Indonesia \\ Tarmedi@upi.edu
}

\begin{abstract}
ABSTRAK
Perkembangan sistem operasi dan era digital adalah dua aspek yang berhubungan dan terintegrasi. Salah satu sistem operasi yang berkembang saat ini adalah sistem operasi linux yang didirikan pada tahun 1991, perkembangan linux tidak sebanding dengan usia yang telah lama, hal tersebut bisa terlihat dari pengguna sistem operasi yang masih rendah. Penurunan keputusan penggunaan sistem operasi linux dapat ditangani dengan cara menganalisis perbedaan prilaku individu.

Penelitian ini bertujuan untuk mengetahui gambaran perbedaan individu, keputusan menggunakan, pengaruh perbedaan individu terhadap keputusan menggunakan sistem operasi linux di Indonesia. Unit analisis dalam penelitian ini adalah pengguna sistem operasi linux di Indonesia. Variabel bebas (X) dalam penelitian ini adalah perbedaan individu, serta variabel terikat (Y) yaitu keputusan menggunakan. jenis penelitian yang digunakan ada deskriptif verifikatif dan metode yang digunakan yaitu explanatory survey dengan teknik sampel random sampling dengan jumlah sebanyak 100 responden. Teknik analisis yang digunakan dalam penelitian ini adalah regresi linier sederhana dengan alat bantu software komputer SPSS 21.0

Hasil temuan penelitian ini dapat diketahui bahwa perbedaan individu memiliki pengaruh sebesar 74,82\% terhadap keputusan menggunakan dengan tingkat kolerasi sangat kuat. Berdasarkan hasil penelitian ini direkomendasikan sebagai dasar untuk dilakukannya penelitian lain mengenai perbedaan individu terhadap keputusan menggunakan dengan indikator dan objek yang berbeda.
\end{abstract}

Kata kunci: Perbedaan Individu, Keputusan Menggunakan

Perkembangan teknologi yang

kompetitif pada saat ini telah memberikan kontribusi yang besar dalam dunia bisnis, para pengusaha memanfaatkan teknologi sebagai suatu strategi untuk mencapai tujuannya (mencapai laba yang maksimal). Dengan demikian para pemasar harus cerdas dalam mengambil tindakan pada perkembangan teknologi yang terjadi dimasyarakat. Era modern pada saat ini menjadikan teknologi menjadi salah satu hasil kebudayaan manusia, karena teknologi sudah berada pada salah satu kebutuhan.

Kemajuan pada teknologi dan informasi ini bisa terlihat dari pengiriman komputer pribadi mobile akan tumbuh menjadi sekitar 809 juta unit pada 2017, dibandingkan hanya 347 juta unit pada tahun 2012. Tim riset dari NPD memprediksi bahwa jumlah pengiriman tablet akan tumbuh dari 121 juta tablet yang dikirim hari ini menjadi 416 juta unit pada 2017, yang mana pada saat bersamaan akan mengambil alih posisi laptop/notebook untuk menjadi perangkat komputer pribadi yang paling populer didunia. Sedangkan pengiriman laptop/notebook akan tumbuh dari 208 juta unit pada tahun 2012 menjadi 393 juta unit pada tahun 2017. (http://inovasi.com Akses pada 3 januari 2014, Pukul 10:54).

Kebutuhan komputer ataupun gadget yang terus meningkat dari tahun ketahun menjadi peluang bisnis perusahaan sistem operasi menjadi peluang bisnis yang cemerlang menghadapi era digital persaingan perusahaan dalam operating system (OS) di Indonesia seperti windows, max, dan linux yang terus melakukan inovasi. Microsoft merupakan sistem operasi komputer terbesar dengan persentase $91,51 \%$ dan Mac OS di posisi kedua dengan persentase $7,2 \%$. Sisanya dimiliki oleh Linux dengan persentase

1,28\%(Sumber:http://www.loveindonesia.com/) - Dalam perkembangan sistem operasi di Indonesia windows menguasai pasar lebih besar dibandingkan dengan Mac, dan linux. Linux merupakan sistem operasi yang sampai saat ini belum familiar dikalangan masyarakat Indonesia, meski sistem operasi ini sudah lama perkembangannya. 
Linux merupakan diciptakan oleh linux Benedict Torvalds pada tahun 1991, dan masih dikembangkan hingga sekarang oleh banyak sukarelawan, sistem operasi linux memberikan kebebasan kepada para penggunanya untuk memodifikasi sumber kode-kode program. Berikut merupakan rata-rata pengguna sistem operasi linux pada Tabel 1

\section{TABEL I}

RATA-RATA PENGGUNA SISTEM OPERASI TAHUN 2011-2013

\begin{tabular}{|c|l|c|c|c|}
\hline \multirow{2}{*}{ NO } & \multirow{2}{*}{$\begin{array}{c}\text { SISTEM } \\
\text { OPERAS }\end{array}$} & \multicolumn{2}{|c|}{ TAHUN } \\
\cline { 3 - 5 } & I & $\mathbf{2 0 1 1}$ & $\mathbf{2 0 1 2}$ & $\mathbf{2 0 1 3}$ \\
\hline $\mathbf{1}$ & Linux & $\mathbf{4 , 7 \%}$ & $\mathbf{5 , 1 \%}$ & $\mathbf{4 , 9 \%}$ \\
\hline 2 & Mac & $7,0 \%$ & $8,3 \%$ & $8,9 \%$ \\
\hline 3 & Windows & $88,3 \%$ & $86,6 \%$ & $86,2 \%$ \\
\hline
\end{tabular}

Sumber: Dari berbagai sumber . Akses pada 11 februari 2014. Pukul 09.30

Tabel 1 tersebut menunjukan bahwa linux mengalamai penurunan pada tahun 2012 sebesar 5,1\%, dan pada tahun 2013 sebesar 4,9\% sedangkan Mac mengalami kenaikan yaitu dari $8,3 \%$ menjadi $8,9 \%$, penurunan linux lebih besar jika dibandingkan dengan windows, yaitu dari $86,6 \%$ menjadi $86,2 \%$. Penurunan rata-rata pengguna linux tersebut diindikasikan dengan pengguna sistem operasi linux yang menurun. Hal tersebut bisa dilihat dari menurunnya registrasi linux pada Gambar dibawah ini.

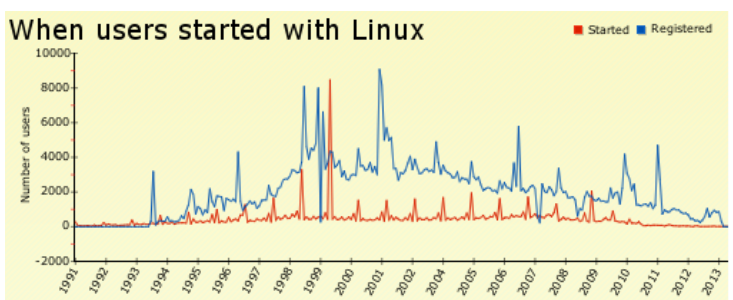

Sumberhttp://linuxcounter.net/places/stat $\underline{\mathrm{html}}$

GAMBAR 1 FLUKTUASI PENGGUNA LINUX

Gambar 1.1 bahwa fluktuasi tingkat registrasi linux terus menurun, berdasarkan dara linux counter tersebut mengindikasikan bahwa pengguna linux menurun, terbukti pada tahun 2011 mengingkat hingga 6000 user yang registrasi, dari tahun 2011 sampai tahun 2013 terus mengalami penurunan, khusunya di tahun 2013 fluktuasinya hingga ke titik 0 ini menunjukan tingkat terendah dari sebelumnya. Penurunan tersebut di indikasikan dengan penggunaan

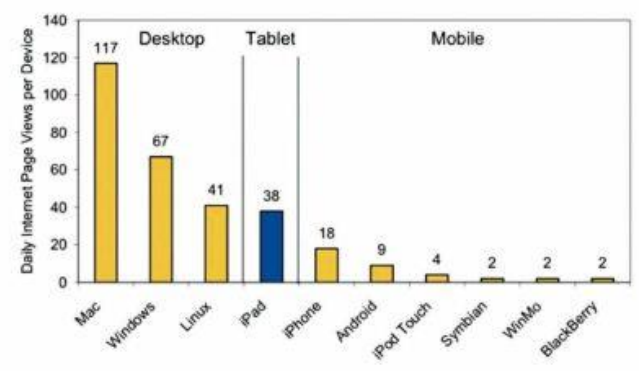

Source: Company data, comscore, Gartner, Net Applications, Morgan Stanley Research

Sumber:Http://www.strangeloopnetworks $\underline{\mathrm{com}}$

\section{GAMBAR 2 \\ INTENSITAS MENGGUNAKAN INTERNET}

Sistem operasi Linux pada desktop semakin menurun, banyak alasan yang menjadi faktor rendah dan menurunnya pengguna Linux, sehingga para pengguna komputer/laptop tidak menggunakan sistem operasi Linux, yang mengakibatkan rendahnya keputusan untuk menggunakan sistem operasi linux, selain itu penggunaan sistem operasi linux dalam mengakses internet juga rendah jika dibandingkan dengan sistem operasi lainnya pada Gambar 3

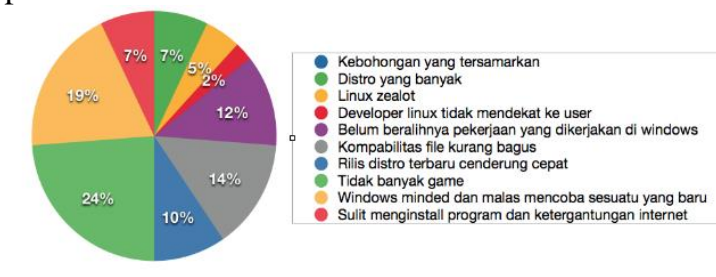

Sumber: http://netsains.net. Akses pada 8 januari 2013

\section{GAMBAR 3 \\ RISET FAKTOR LINUX TIDAK POPULER}

Berdasarkan riset tersebut menunjukan bahwa alasan di Indonesia tidak populer, yaitu pertama tidak banyak games $24 \%$, windows minded 19\%, 14\% kompabilitas file kurang bagus, belum beralihnya pekerjaan yang dikerjakan di windows $12 \%$, rilis distro terlalu cepat $10 \%$, distro yang banyak $7 \%$, sulit menginstal program dan ketergantungan $7 \%$, Linux zealot $5 \%$, dan yang terakhir developer linux yang tidak mendekat ke user $2 \%$. Dengan demikian karena faktor games yang lebih mendominasi. Keberagaman penerimaan individu dalam penerimaan teknologi sistem operasi linux cenderung sangat berbeda, karena dipengaruhi oleh proses penerimaan teknologi setiap individu yang berbeda. 
Model yang mengukur faktor-faktor penerimaan teknologi adalah Technology Acceptance Model (TAM) merupakan salah satu model penelitian yang paling berpengaruh dalam studi tentang faktor-faktor penentu sistem informasi dan penerimaan teknologi informasi untuk memprediksi niat untuk menggunakan dan penerimaan sistem informasi dan teknologi informasi oleh individu yang dikembangkan oleh para ahli.

Teori Davis (1989) merupakan faktorfaktor penentu penentu penerimaan teknolgi informasi untuk memprediksi niat untuk menggunakan ada dua faktor penentu yaitu presepsi kemudahan penggunaan (Perceived ease of use) dan kegunaan yang dirasakan (perceived usefulness). Teori tersebut merupakan determinan yang menghubungkan kepada keputusan menggunakan dan berkaitan dengan penerimaan teknlogi yang dirasakan oleh setiap individu, karena individu yang akan terlibat langsung dengan penggunaan teknologi.

Kemudahan penggunaan sistem operasi linux telah menggunakan graphical user interface (GUI) yang lebih praktis, sehingga semakin memudahkan para pengguna. Untuk mempermudah dalam menginstal untuk notebook, instalasi lewat flashdisk, linux fortable. Dan linux liveCd merupakan perkembangan linux yang signifikan. Ketersediaan Wubi installer turut memudahkan pengguna windows memasang dan membuang aplikasi biasa, pengguna yang membutuhkan waktu beralih ke linux juga difasilitasi dengan perangkat lunak secara gratis yang bernama ( Winehq.org) dengan wine, pengguna tetap bisa menggunakan semua perngkat lunak berbasis windows dalam sistem operasi linux. Hal tersebut memungkinkan pengguna bisa menggunakan sistem operasi lebih dari satu sistem operasi dalam satu komputer.

Aplikasi Mesin virtual, dengan teknologi ini linux bisa digunakan diatas windows. Virtualisasi bisa dilakukan dengan menggunakan perangkat Sun Microsystem, yakni Sun Xvm Virtualbox. Bisa mengunduhnya disitus Sun.com. sebelum ke mesin virtual tetap saja harus mengunduh CD ISO Linux disitus distro masing-masing. Keunggulannya dengan menginstal mesin virtual dimana pengguna dapat memakai beberapa sistem operasi sekaligus dengan jenis sistem operasi yang berbeda sekalipun pada satu komputer dan juga pada satu waktu tanpa harus mengganti sisten operasi yang sudah terpasang pada komputer sebelumnya. Berdasarkan aplikasi tersebut memungkinkan pengguna menggunakan sistem operasi yang berbeda dalam satu unit perangkat komputer, yaitu windows dan linux, yang bisa dipakai secara bersamaan.

Berikut merupakan hasil penelitian kepada responden yang menggunakan sistem operasi yang berbeda.

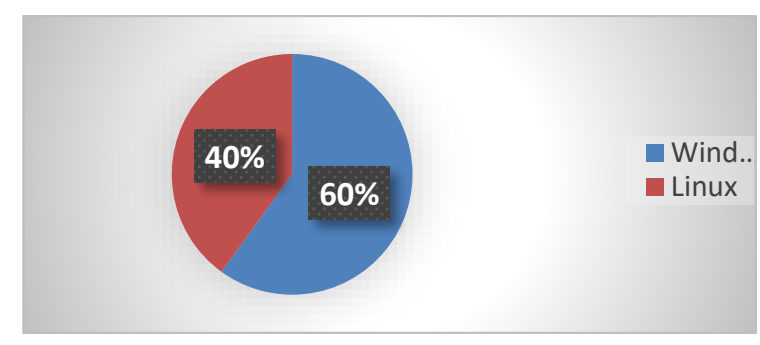

Sumber: Prapenelitian 2014

\section{GAMBAR 4 \\ PERSENTASE INTENSITAS PENGGUNAAN WINDOWS DAN LINUX}

Hasil penelitian tersebut menunjukan bahwa responden lebih sering menggunakan sistem operasi windows dibandingkan dengan linux. $60 \%$ menunjukan lebih sering menggunakan sistem operasi windows dibandingkan dengan sistem operasi linux yang hanya $40 \%$ dari 30 responden. Dari hasil penelitian tersebut dapat diartikan bahwa dalam memilih, memakai dan membeli barang atau jasa merupakan bentuk nyata dari dorongan internal seseorang yang pada akhirnya menggunakan barang atau jasa tersebut.

Rendahnya penggunaan pada sistem operasi Linux jika dibandingkan dengan sistem operasi windows, dengan kondisi tersebut linux atau para pengembang harus mempunyai strategi yang baik dengan tidak mengabaikan kerikatan ataupun keinginan konsumen untuk mengidentifikasi kebutuhan, keinginan konsumen, dan pihak perusahaan harus memahami prilaku konsumen, Berdasarkan kesadaran dan pengetahuan masyarakat sehingga kemajuan teknologi tidak dapat dirasakan secara merata dikalangan masyarakat, hal tersebut bisa dilihat dari rendahnya pengguna komputer/laptop menggunakan sistem operasi Linux.

Penggunaan teknologi akan senantiasa muncul persepsi baik itu sebelum atau sesudah menggunakan, persepsi muncul dari stimuli dari proses penglihatan dan proses penggunaan pada suatu teknologi. Dalam penerimaan teknologi salah satunya adalah persepsi kemudahan penggunaan Menurut Ching-Chen at al (2011:124) Kemudahan penggunaan adalah sejauh mana seseorang percaya bahwa menggunakan sistem informasi tertentu atau teknologi informasi akan bebas dari upaya. Berdasarkan hal tesebut para pengguna penerima dari teknologi dengan harapan setiap teknologi 
yang diterimanya mudah untuk digunakan. Berikut merupakan hasil penelitian persepsi pengguna terhadap penggunaan sistem operasi linux.

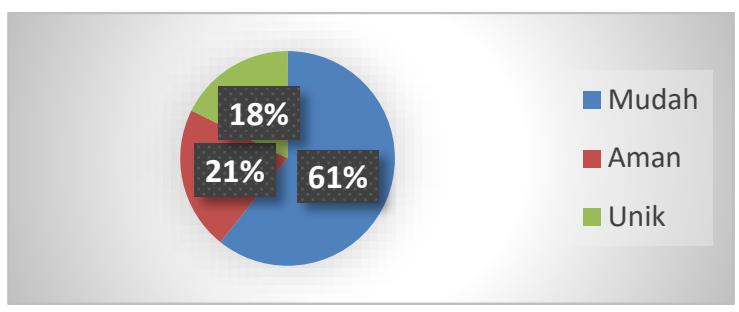

Sumber: Hasil pengolahan penelitian 2014

GAMBAR 5 PERSEPSI MENGGUNAKAN SISTEM OPERASI LINUX

Dari hasil penelitian tersebut responden menunjukan bahwa dengan menggunakan linux lebih mudah sebesar $61 \%$, aman dari virus $21 \%$ dan karena unik sebesar $18 \%$. Linux memiliki kelebihan tersendiri dalam sistem operasi yaitu dalam kemudahan, kemanan terhadap virus dan dalam kelengkapan program, program aplikasi, konfigurasi sistem, dukungan hadware, manajemen proses, system file, waktu pengoprasian, system distribusi. Dalam proses penerimaan dan konsumsi yang berbeda menurut Ratih Hurriyati (2008:79) mendefinisikan, "Perbedaan individu merupakan suatu proses psikologis yang mempengaruhi individu dalam memperoleh, mengkonsumsi serta menerima barang dan jasa serta pengalaman". Berdasarkan pengertian tersebut Berikut merupakan dorongan individu menggunakan sistem operasi linux.

TABEL II

\section{DORONGAN MENGGUNAKAN} SISTEM OPERASI LINUX

\begin{tabular}{|l|c|c|}
\hline \multicolumn{1}{|c|}{ Faktor } & Frekuensi & Persentase \\
\hline Pengaruh Akademis & 18 & $44 \%$ \\
\hline Pengaruh Hobi & 6 & $20 \%$ \\
\hline $\begin{array}{l}\text { Mengembangkan } \\
\text { Kreatifitas }\end{array}$ & 8 & $26 \%$ \\
\hline Pengaruh Pekerjaan & 3 & $10 \%$ \\
\hline \multicolumn{1}{|c|}{ Jumlah } & $\mathbf{3 0}$ & $\mathbf{1 0 0 \%}$ \\
\hline
\end{tabular}

Sumber: Hasil pengolahan prapenelitian 2014

Dari hasil penelitian tersebut menunjukan bahwa faktor akademis yang lebih mempengaruhi individu dalam menggunakan sistem operasi linux, yaitu sebesar $44 \%$, karena mengembangkan kreatifitas $26 \%$, pengaruh hobi $20 \%$ dan pengaruh pekerjaan sebesar $10 \%$. Atas dasar dorongan yang berbeda pada individu dalam menggunakan sistem operasi linux maka setiap individu mempunyai dorongan yang berbeda dalam keputusan menggunakan sistem operasi linux.

Berdasarkan pendapat diatas maka perlu dilakukan penelitian dengan tema "Perbedaan individu terhadap keputusan menggunakan sistem operasi linux. (Survei pada pengguna sistem operasi linux di Indonesia)".

Tujuan dari penelitian ini adalah memperoleh temuan mengenai: (1) Untuk memperoleh gambaran dan temuan mengenai perbedaan individu pada pengguna linux di Indonesia. (2) Untuk memperoleh gambaran keputusan menggunakan pada pengguna sistem operasi linux di Indonesia. (3) Untuk memperoleh seberapa besar pengaruh perbedaan individu terhadap keputusan menggunakan sistem operasi linux.

\section{KAJIAN PUSTAKA}

Dalam proses penerimaan teknologi terdapat faktor yang sangat mempengaruhi dalam keputusan untuk menggunakan teknologi tersebut, teori yang berhubungan salah satunya adalah prilaku konsumen, yang menganalisis prilaku baik yang berpengaruh dari luar dirinya atau dari dalam dirinya yang mendorong untuk berprilaku. Pengertian prilaku konsumen menurut Hawkins, dan Mothersbaugh (2013:6), menyatakan "Counsumer behaviour is the study if individual, groups or organizations, and the processes the use the select, secure, use, and dipose of product, service, experience or ideas to statisfy needs and the impact that these processes have on the consumer and society". Prilaku konsumen merupakan studi tentang bagaimana indivdu, kelompok dan organisasi serta proses yang dilakukan untuk memilih, mengamankan, menggunakan dan menghentikan produk, jasa, pengalaman atau ide untuk memuaskankan kebutuhan dan dampaknya terhadap konsumen dan masyarakat.

Pengaruh dalam dirinya (perbedaan individu) menurut Schiffman dan Kanuk (2010:36) meliputi (1) Motivasi (2) Persepsi (3) Pembelajaran (4) Kepribadian (5) Sikap. Lima dimensi tersebut menjadi ukuran untuk keputusan membeli atau menggunakan.

Kotler and Keller (2012:192) menyatakan bahwa keputusan pembelian adalah "The consumer forms preference among the brands in the choice set and may also form an intention to buy the most preferred brand". Konsumen membentuk preferensi di antara merek di set pilihan dan juga dapat membentuk niat untuk membeli merek yang paling disukai.

Faktor yang mempengaruhi individu dalam berprilaku adalah karena ada dorongan dari internal maupun dari external yang akan mempengaruhi individu dalam membeli atau menggunakan suatu produk sehingga akan berdampak pada keputusan dalam mengkonsusmsi atau menggunakan. 
Berdasarkan uraian tersebut maka dapat diketahui bahwa perbedaan individu mempengaruhi keputusan menggunakan, adapun paradigma dalam penelitian ini adalah:

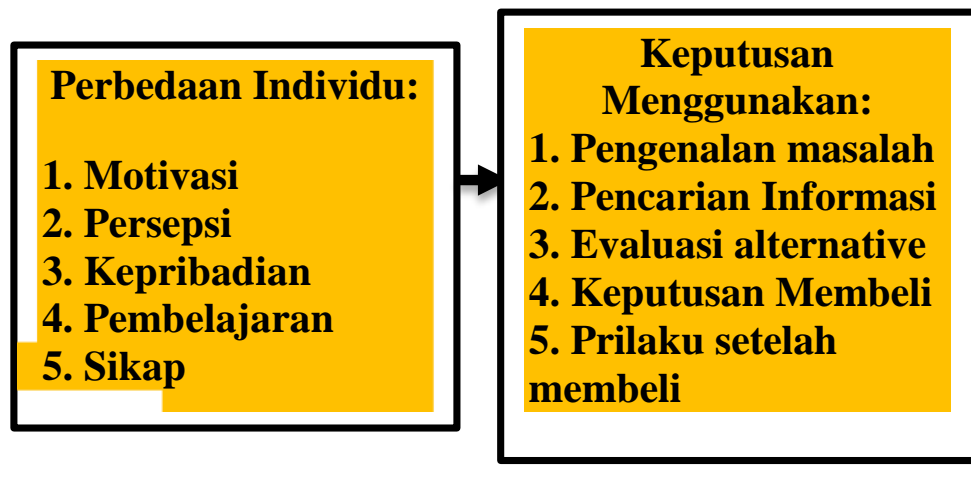

\section{GAMBAR 6 \\ PARADIGMA PENELITIAN}

\section{METODE PENELITIAN}

Penelitian ini menggunakan pendekatan manajemen pemasaran khususnya mengenai pengaruh perbedaan individu terhadap keputusan menggunakan. Adapun yang menjadi objek penelitian sebaagi variabel bebas (eksogen) adalah pebedaan individu (X) dengan sub motivasi, persepsi, kepribadian, pembelajaran dan sikap. Kemudian objek penelitian yang menjadi variabel terikat (endogen) adalah keputusan pembelian (Y) yang meliputi pengenalan masalah, pencarian informasi, evaluasi alternative, keputusan membeli, dan prilaku setelah membeli. Objek yang dijadikan responden dalam penelitian ini adalah pengguna sistem operasi linux di Indonesia.

Penelitian ini dilakukan pada kurung waktu kurang dari satu tahun, maka penelitian ini menggunakan metode cross sectional method. Menurut Husain Umar (2008:45) menyatakan bahwa metode penelian cross sectional yaitu penelitian dengan cara mempelajari objek dalam kurung waktu tertentu (tidak berkesinambungan dalam jangka waktu panjang) dalam penelitian yang menggunakan metode ini, informasi dari sebagian populasi dikumpulkan langsung kejadian secara empirik dengan tujuan untuk mengetahui pendapat dari sebagian populasi terhadap objek yang sedang diteliti di lapangan.

Berdasarkan variabel-variabel yang diteliti maka jenis penelitian ini adalah penelitian deskriptif dan verifikatif. Menurut Travers Travens dalam Husain Umar (2008:21) penelitian menggunakan metode deskriptif adalah penelitian yang dilakukan untuk mengetahui nilai variabel mandiri, baik satu variabel atau lebih (independent) tanpa membuat perbandingan atau menghubungkan dengan variabel lain.
Agar memperoleh sampel yang representatif dari populasi, maka setiap subjek dalam populasi diupayakan untuk memiliki peluang yang sama untuk menjadi sampel. Adapun rumus yang digunakan untuk mengukur sampel, digunakan rumus Slovin (Husain Umar, 2008:141), yakni ukuran sampel yang merupakan perbandingan dari ukuran populasi dengan presentasi kelonggaran ketidaktelitian, karena dalam pengambilan sampel dapat ditolelir atau diinginkan. Dalam pengambilan sampel ini digunakan taraf kesalahan sebesar 10\%. Sampel yang digunakan dalam penelitian ini adalah 100 responden.

Secara statistik hipotesis yang akan diuji berada pada taraf kesalahan 0,05 dengan derajat kebebasan (dk) (n-2) serta berada pada uji pihak kanan. Serta pada uji satu pihak, yaitu uji pihak kanan. Secara statistik, hipotesis yang akan diuji dalam rangka pengambilan keputusan penerimaan atau penolakan hipotesis dapat dirumuskan sebagai berikut:

$\mathrm{H}_{\mathrm{o}}: p \leq 0$, artinya tidak terdapat pengaruh positif dari perbedaan individu terhadap keputusan menggunakan sitem operasi linux

$\mathrm{H}_{\mathrm{a}}: p>0$, artinya terdapat pengaruh positif dari perbedaan individu terhadap keputusan menggunakan.

\section{HASIL PENELITIAN DAN PEMBAHASAN}

\section{Pembahasan Deskripstif}

\section{a. Perbedaan Individu}

Berdasarkan hasil penelitian yang bersifat empiris mengenai perbedaan individu, dihasilkan temuan bahwa dimensi kepribadian telah memberikan kontribusi cukup tinggi bagi pengguna sistem operasi linux.

\section{b. Keputusan Menggunakan}

Berdasarkan hasil penelitian yang bersifat empiris mengenai keputusan menggunakan sistem opersai Linux, dihasilkan temuan bahwa dimensi keputusan membeli telah memberikan kontribusi cukup tinggi dalam mencapai keputusan menggunakan.

\section{Pembahasan Verifikatif}

Dengan menggunakan program SPSS 21.0 for Windows, diperoleh hasil koefisien regresi sebagai berikut:

TABEL III

MODEL REGRESI LINIER SEDERHANA

Coefficients $^{\mathrm{a}}$

\begin{tabular}{|l|c|c|c|c|}
\hline Model & $\begin{array}{c}\text { Unstandardized } \\
\text { Coefficients }\end{array}$ & $\begin{array}{c}\text { Standardized } \\
\text { Coefficients }\end{array}$ & $\mathrm{t}$ & Sig. \\
\cline { 2 - 5 }
\end{tabular}




\begin{tabular}{|c|c|c|c|c|c|}
\hline & B & Std. Error & Beta & & \\
\hline (Constant) & $\mathbf{5 , 5 8 3}$ & 1,456 & & 3,834 & 0,000 \\
Perbedaan & $\mathbf{0 , 2 1 1}$ & 0,043 & 0,865 & 17,061 & 0,000 \\
Individu & & & & & \\
& & & & & \\
\hline
\end{tabular}

Sumber: Hasil Pengolahan Data 2014

Berdasarkan Tabel 4.22 Mengenai koefisien regresi, maka diperoleh persamaan regresi linier antara perbedaan individu dan keputusan menggunakan, yaitu sebagai berikut: $\mathrm{Y}=\mathrm{a}+\mathrm{Bx}$ adalah keputusan menggunakan $(\mathrm{Y})=$ $5,583+0,732$, artinya semakin besar keputusan menggunakan (Y) yang terjadi mengikuti perubahan perbedaan individu (X) yaitu sebesar 5,583 .

Selain itu dapat diketahui besarnya $t_{\text {hitung }}$ melalui uji $t$ atau $t_{\text {tabel, }}$, besarnya $t_{\text {hitung }}$ melalui uji t yaitu sebesar 17,061, $\mathrm{t}_{\text {tabel }}=1,987$ maka dapat disimpulkan Ho DITOLAK, artinya ada hubungan linier antara perbedaan individu dengan keputusan menggunakan dengan taraf signifikansi 0,000 yang lebih kecil dari taraf signifikansi $5 \%$ pada uji satu pihak dengan derajat kebebasan (dk)n-2, $(\mathrm{dk})=100-2$ maka $\mathrm{dk}=98$. Karena probabilitas $(0,000)$ jauh lebih kecil dari 0,05 maka model regresi bisa dipakai untuk memprediksi keputusan menggunakan atau dapat disimpulkan bahwa perbedaan individu berpengaruh terhadap keputusan menggunakan.

Berdasarkan tabel koefisien regresi diatas, maka diperoleh persamaan regresi linier antara perbedaan individu dengan keputusan menggunakan, yaitu sebagai berikut:

$$
\mathbf{Y}=\mathbf{a}+\mathbf{B x}
$$

\section{Keputusan Menggunakan $=\mathbf{5 , 5 8 3}+\mathbf{0 , 7 3 2}$ Perbedaan Individu}

Berdasarkan persamaan regresi diatas, besar perubahan keputusan menggunkan (Y) yang terjadi mengikuti perubahan perbedaan individu (X) yaitu sebesar 5,583 artinya bahwa jika tidak ada perbedaan individu $(\mathrm{X}=0)$ maka keputusan menggunakan sebesar 5,583 satu satuan nilai. Koefisien regresi 0,732 satu satuan nilai artinya setiap terjadi peningkatan setiap perbedaan individu akan meningkatkan keputusan menggunakan sebesar 0,732 satu satuan nilai, dan sebaliknya jika terjadi penurunan perbedaan individu akan menurunkan keputusan menggunakan sebesar 0,732 satu satuan nilai.
Setelah melakukan pengujian hipotesis, maka langkah selanjutnya adalah melakukan perhitungan koefisien determinasi (KD) untuk pengaruh perbedaan individu terhadap keputusan menggunakan. Koefisien determinasi adalah persentase besarnya pengaruh variabel $\mathrm{X}$ terhadap variabel $\mathrm{Y}$.

\section{TABEL IV} MODEL SUMMARY

\begin{tabular}{|l|c||r|r|c|}
\hline Model & $\mathrm{R}$ & $\begin{array}{c}\mathrm{R} \\
\text { Square }\end{array}$ & $\begin{array}{r}\text { Adjusted } \\
\text { R Square }\end{array}$ & $\begin{array}{c}\text { Std. Error } \\
\text { of the } \\
\text { Estimate }\end{array}$ \\
\hline 1 & $0,865^{\mathrm{a}}$ & 0,748 & 0,746 & 2,68778 \\
\hline
\end{tabular}

Sumber: Hasil Pengolahan Data 2014

Berdasarkan tabel 4.26 Model summary output SPSS 21.0, dapat ketahui bahwa korelasi atau hubungan antar variabel perbedaan individu dengan variabel keputusan menggunakan memperoleh hasil sebesar 0,865 (positif), ini artinya sesuai dengan pedoman kolerasi menurut Sugiyono (2013:250) maka kolerasi antara perbedaan individu dengan keputusan menggunakan katergori sangat kuat (0,80-1.000) dengan Standar Error Of Estimate (SEE) sebesar 2,687 untuk variabel keputusan menggunakan. Model Summary diatas diperoleh angka R square yang diperoleh sebesar 0,748. Hal ini menunjukan bahwa variabel perbedaan individu (X) berpengaruh terhadap keputusan menggunakan (Y) sebesar $74 \%$ yang artinya $74 \%$ keputusan menggunakan disebabkan oleh perbedaan individu dan $28 \%$ dipengaruhi oleh faktor lain.

\section{KESIMPULAN}

Berdasarkan pembahan teori, hasil penelitian dan pengujian analisis regresi sederhana yang dilakukan mengenai pengaruh perbedaan individu terhadap keputusan menggunakan sistem operasi linux dapat disimpulkan bahwa:

1. Hasil penelitian menyatakan bahwa perbedaan individu pada pengguna sistem operasi linux di Indonesia berada pada kategori tinggi. Hal ini menunjukan bahwa perbedaan individu pada pengguna sistem operasi linux memberikan dampak yang baik terhadap keputusan menggunakan sistem operasi linux.

2. Hasil penelitian menggambarkan bahwa keputusan menggunakan sistem operasi linux di indonesi berada pada kategori sangat tinggi. Hal ini menunjukan bahwa keputusan penggunaan sistem operasi linux sudah baik. Penilaian paling tinggi yaitu keputusan membeli dan dimensi yang memiliki penilaian paling rendah yaitu keputusan setelah membeli. 
3. Hasil penelitian menyatakan bahwa perbedaan individu mempunyai pengaruh positif terhadap keputusan menggunakan dengan tingkat kolerasi sangat kuat. Hal ini menunjukan bahwa semakin bervariasi perbedaan individu, maka akan semakin tinggi pula keputusan menggunakan. Dengan pengetahuan tentang konsep tersebut maka sumber manusia yang dihasilkan oleh pendidikan manajemen bisnis selain ahli dalam bidang keuangan dan kewirausahaan, juga ahli dalam bidang pemasaran.

Berdasarkan hasil penelitian, maka penulis merekomendasikan beberapa hal mengenai perbedaan individu yang dapat meningkatkan keputusan menggunakan sistem operasi linux, yaitu sebagai berikut:

1. Perbedaan individu pada penggunaan sistem operasi linux dapat ditingkatkan melalui pemahaman dan pengetahuan pengguna. dan mempermudah proses penggunaannya, sehingga para pengguna tidak akan merasa kesulitan dalam proses penggunaan sistem operasi linux.

2. Keputusan menggunakan sistem operasi linux dapat ditingkatkan melalui aspek kepercayaan dan aspek kemudahan dalam menggunakan sistem operasi linux.

3. Hasil penelitian menyatakan bahwa perbedaan individu berpengaruh positif terhadap keputusan menggunakan, maka penulis merekomendasikan agar perusahaan semakin mempermudah dalam proses penggunaan sistem operasi linux.

\section{DAFTAR PUSTAKA}

Chen, Ching-Yaw et al. 2012. Exploration Of The Differences In Taiwanese Women's Purchasing Decisions Towards Luxury Goods And General Products. Departemen Of Information Management Vol. 6(2), pp. 548-561.

Davis, F. D. 1989. Perceived Usefulness, Perceived Ease Of Use. And User Acceptance Of Information Technology. MIS Quarterly (13:3).pp 319-340.

Hawkins, D.I, amd David L. Mothersbaugh. 2013. Consumer Behaviour: Building Marketing Strategy, 11ed, Mc Graw Hill: Usa.

Hurriyati, Ratih. 2008. Bauran Pemasaran
Dan Loyalitas Konsumen. Bandung: CV. Alfabeta.

Kotler, Philip and Gary Amstrong. 2012. Principle Of Marketing 14 Edition. United States of America: Prentice Hall.

Kotler, Philip \& Kevin L. Keller. 2012.

Marketing Manajemen, $14^{\text {th }}$ Edition Pearson International

Edition, New Jersey: Prentice Hall.

Shiffman, Leon G dan Lesli Lazier Kanuk. 2010. Consumer behaviour $10^{\text {th }}$

Edition. Pearson.

USA:

Prentice Hall.

Sugiyono. 2008. Metode Penelitian Pendidikan. Bandung. Alfabeta 2013 Metode Penelitian Pendidikan. Bandung. Alfabeta

Umar, Husein. 2008. Metode Riset Bisnis, Jakarta: PT Gramedia Pustaka utama 